\title{
ОСОБЕННОСТИ АДМИНИСТРАТИВНОГО УПРАВЛЕНИЯ В СФЕРЕ ТУРИЗМА
}

\author{
АСКЕРЛИ Гюлер Сахиб гызы - докторант кафедры «Конституционного \\ права» Бакинского государственного университета
}

DOI 10.32782/LAW.UA.2020.3.8

В статье автор отмечает, ито туризм - одна из самъгх удивительньх сбер соииокультурной жизни людей. Это независимая сочиально-якономическая подсистема, и в то же время предельно скоростная интегрированная система высокого уровня. Понятие «туризм» как сочиально-якономическое и в то же время культурное понятие звучит созвучно понятиям «вкономика», «общество» $и$ «экологическая среда».

Ключевъе слова: туризм, понятие, конституиия, закон, республика.

Первый закон связанный с туризмом среди государств-членов Содружества Независимых Государств, был принят Украиной 15 сентября 1995 года [1]. Определение туризма в законодательных актах, регулирующих туристическую деятельность указанных государств, является, с учетом некоторых незначительных отличий, аналогичным. Например, во всех этих странах в законодательном определении туризма отражено, что физическое лицо не должно заниматься оплачиваемой деятельностью в стране (месте), где оно будет временно находиться. Из стран СНГ только в Законе Республики Таджикистан «О туризме» установлено, что паломничество в хадж не входит в туризм [2], а Закон Республики Казахстан «О туристической деятельности в Республике Казахстан» определяет минимальный (1 ночь) и максимальный 1 (один) год срок пребывания физических лиц в стране (месте) временного пребывания [3].
Считаем необходимым отметить, что проект конституционных основ туризма в Азербайджанской Республике был подготовлен под руководством Общенационального Лидера Гейдара Алиева и нашел свое отражение в 1-ой части статьи 37 Основного Закона независимой Азербайджанской Республики, принятого на всенародном голосовании (референдуме) 12 ноября 1995 года. Согласно этой норме, «каждый имеет право на отдых» [4]. Следовательно, государство должно обеспечить право граждан на отдых через свои соответствующие органы.

Профессор А.Г.Рзаев справедливо отмечает, что «с приходом к власти Общенационального лидера Гейдара Алиева, хаос, официальный произвол, одним словом, беззаконие в жизни государства были устранены в короткие сроки, а деятельность государства и общества перешла в правовую плоскость. Впервые проводятся политические, правовые и экономические реформы, принята первая Конституция независимого Азербайджана (в 1995 году), а также была создана новая система государственности. Достойным преемником системы государственности, созданной Гейдаром Алиевым, стал Президент Азербайджанской Республики Ильхам Алиев» [5].

В современный период существуют различные модели государственного регулирования туризма. К таким моделям можно отнести:

$\S$ современное состояние туристического рынка; 
$\S$ особенности туристического потребления;

$\S$ специфику туристической продукции;

$\S$ особенности запросов и предложений;

$\S$ роль туризма в современной экономике;

$\S$ влияние туризма и его элементов на другие сектора экономики;

$\S$ изучение других внешних факторов, сопровождающих развитие туризма (в том числе, экологического и социокультурного воздействия), и др.

В целом, в качестве основных, в литературе приняты следующие модели государственного регулирования туризма, а именHO:

- планово-командная модель;

- рыночная модель;

- модель переходного периода [6, с. 160].

Как следует из названия, планово-командная модель была типичной для государств с социалистической идеологией. Это, конечно, было связано с плановым характером экономики. Например, в связи с тем, что бывший СССР был закрытым государством, к туризму подходили с плановой позиции, то устанавливались определенные ограничения как по количеству, так и по материально-финансовым затратам туристов, прибывающих в страну, и советских граждан, выезжающих из страны в зарубежные государства. Поэтому, иностранцы, совершавшие путешествие по СССР, передвигались строго по запланированным маршрутам и под контролем специальных гидов. Конечно, современное мировое сообщество относилось к этому неоднозначно, и, вследствие этого, бывшее советское государство не рассматривалось в качестве места, привлекательного для туристов.

Рыночная модель туризма, сформировавшаяся в период после Второй мировой войны, - это цивилизованная рыночная модель туризма. Рыночная модель туризма характеризуется следующими особенностями: продукт индустрии туризма - это платеж, и этот платеж реализуется за счет потребителя; соответствующие министерства, администрации, советы по туризму и развитию, туристические информационные центры, туристические агентства, территориальные органы управления туризмом, туристическая полиция и другие органы действуют в качестве органов управления и регулирования туризма.

Как указано в литературе, «с точки зрения предпринимательства, в рыночной модели туризм рассматривается как промышленность, а туристический процесс - как запрос, предложения со стороны туриста (туристическая промышленность). Среди туристических предприятий, к мелкому и среднему бизнесу относят значительное количество предприятий. Однако практический опыт показывает, что отсутствие государственного регулирования процесса развития туризма не может решить проблемы его устойчивого развития» [6, с. 119].

Государственное регулирование важно для нормального и стабильного развития туризма. Әффективность индустрии туризма определяется степенью развития туристической продукции и эффективностью использования туристских ресурсов.

В вышеупомянутом контексте, под туристическим продуктом воспринимают набор услуг, предоставляемых туристам, то есть размещение, транспорт, услуги питания, экскурсии, а также услуги гида-переводчика и другие услуги, предоставляемые в зависимости от цели поездки.

В связи с этим, крайне необходимо активизировать туристическую продукцию, а также повысить деловую активность. Именно благодаря этому на качественном уровне реализуется весь комплекс необходимых мер, связанных с туристической продукцией. Что касается активизации туристической продукции, то предусматривается комплекс мероприятий, направленных на реализацию туристической продукции (реклама, участие в специализированных выставках, ярмарках, организация туристических информационных центров по продаже туристической продукции, издание каталогов, буклетов и др.).

Возникает необходимость подойти к модели туризма переходного периода (на примере Азербайджана) с несколько иных позиций. Как и все другие сферы деятельно- 


\section{Адміністративне право}

сти социальной жизни, туристическая сфера привлекает внимание некоторыми своими противоречиями в переходный период. Переход к новой экономической системе выявляет некоторые свои сложности и трудности, в том числе, и в этой сфере управления. Наиболее существенными противоречиями переходного периода, связанными с управлением туризмом, являются:

$\S$ все туристические услуги носят исключительно платный характер, что явно ощущается как населением страны, так и иностранными гражданами, прибывающими для совершения путешествий из-за рубежа;

$\S$ наличие розничной торговли в сфере туризма;

$\S$ отсутствие историко-культурных ресурсов страны на любом уровне в сфере обслуживания туристов;

$\S$ относительно слабые нормативноправовая база и государственное регулирование в сфере управления туризмом;

$\S$ слабые долгосрочные программы в сфере туризма, а также заметные задержки в реализации существующих программ;

$\S$ «социальный туризм» (Статья 1 Закона Азербайджанской Республики «О туризме» гласит, что социальный туризм - «это поездка, финансируемая государством для социальных нужд» [7]. Другими словами, социальный туризм означает, что определенные категории людей путешествуют за счет средств, выделяемых государством на социальные нужды);

$\S$ наличие определенной диспропорции и розничной торговли в процессе развития сферы туризма.

Следует отметить, что неподготовленность трансформируемой сферы государства к предстоящей работе по туризму во всех цивилизованных странах, в том числе, и в Азербайджанской Республике, может быть связана со следующими причинами: отсутствие контроля над развитием туризма, отсутствие контроля над туризмом в переходный период (несколько лет) отсутствие лицензирования и сертификации в данной области; отсутствие необходимого опыта у органов, на которые возложены задачи по государственному регулированию в сфере управления туризмом, и т. д.

Одна из названных причин - это сохранявшееся до 4 июня 1999 года отсутствие в Азербайджанской Республике закона о туризме. Сегодня государственное регулирование туризма во всех развитых странах мира находится под эгидой соответствующего законодательства. В этом отношении Азербайджанская Республика не составляет исключение. Согласно литературным источникам, «соответствующее законодательство, другие нормативные правовые акты, международные соглашения, а также двусторонние и многосторонние соглашения по туризму играют важную роль в регулировании современного туризма в условиях свободной рыночной экономики».

На наш взгляд, одним из наиболее важных аспектов упомянутых актов является развитие туризма как одной из важных отраслей, превращение его в одну из социально-культурных ценностей народов мира. Опыт стран мира свидетельствует о том, что даже развитые государства добились значительных социально-экономических успехов благодаря развитию туризма.

С точки зрения вышеизложенного, Закон Азербайджанской Республики «О туризме» вносит свой вклад в мировое сообщество в области развития современного туризма.

Важнейшая роль в основах управления туризмом в Азербайджанской Республике отводится, прежде всего, государственному регулированию туризма. Следует отметить, что управление туризмом также является неотъемлемой частью государственного регулирования, и это регулирование представляет собой комплексный процесс. Сюда входит реализация практически всех текущих вопросов, связанных с туризмом, а также выполнение необходимых задач.

Как и во всех странах мира, с точки зрения развития туризма Азербайджанская Республика испытывает потребность в государственном регулировании. С другой стороны, именно регулирование определяет основные направления управления в сфере туризма, обеспечивает создание благоприятных условий для расширения туристиче- 
ской отрасли, ассортимента туристической продукции.

В отличие от других отраслей народного хозяйства, туризм имеет много особенностей, и эти особенности определяют основы управления в этой сфере. В литературе отмечается, что «для туризма характерно, прежде всего, совпадение всего набора товаров и услуг. В то же время, производство и потребление существенно пересекаются во времени и в пространном отношении». Это - не случайное сравнение. Причина кроется в том, что туризм, напоминающий отрасль, имеющую свою специфическую базу, представляет собой один из значимых источников дохода каждого государства, а такие доходы и прибыль создаются на основе индустрии туризма, созданной за счет внутренних возможностей каждого государства. Поэтому одна из основных целей - мобилизация внутренних ресурсов и их более эффективное использование.

\section{ภитература}

1. Закон Украины "О туризме" от 15 сентября 1995 года. http://base.spinform.ru/ show_doc.fwx?rgn $=9550$

2. Закон Республики Таджикистан "О туризме” от 3 сентября 1999 года. http://base. spinform.ru/show_doc.fwx?rgn $=2171$

3. Закон Республики Казахстан от 13 июня 2001 года “О туристской деятельности в Республике Казахстан” https://online.zakon. kz/document/?doc_id $=1023618 \#$ pos $=47 ;-155$

4. Конституция Азербайджанской Республики от 12 ноября 1995 года. Баку: Ганун, 2019

5. Rzayev Ә.H. Şəxsiyyət Dövlət Möcüzə. Bakı: «Bakı Universiteti» nəşriyyatı, 2017

6. Попова Р.Ю. Государственное регулирование становления и развития туризма в России на переходном этапе. Москва: МГУ, 1997

7. Закона Азербайджанской Республики “О туризме" от 4 июня 1999 года. http:// base.spinform.ru/show_doc.fwx?rgn $=2688$

\section{Guler Asgerli \\ FEATURES OF ADMINISTRATIVE MANAGEMENT IN THE FIELD OF TOURISM}

In the article, the author notes that tourism is one of the most amazing spheres of social and cultural life of people. It is an independent socio-economic subsystem, and at the same time, an extremely high-speed, high-level integrated system. The concept of "tourism" as a socio-economic and at the same time cultural concept sounds consonant with the concepts of "economy", "society" and "ecological environment".

Keywords: tourism, concept, constitution, law, republic 